\title{
Refuge
}

Canada's Journal on Refugees

revue canadienne sur les réfugiés

\section{Refugees in Extended Exile: Living on the Edge, by Jennifer Hyndman and Wenona Giles | Borderlands: Towards an Anthropology of the Cosmopolitan Condition, by Michel Agier}

\section{Laura Bisaillon}

Volume 34, Number 1, 2018

Intersectional Feminist Interventions in the "Refugee Crisis"

URI: https://id.erudit.org/iderudit/1050860ar

DOI: https://doi.org/10.7202/1050860ar

See table of contents

Publisher(s)

Centre for Refugee Studies, York University

ISSN

0229-5113 (print)

1920-7336 (digital)

Explore this journal

Cite this review

Bisaillon, L. (2018). Review of [Refugees in Extended Exile: Living on the Edge, by Jennifer Hyndman and Wenona Giles | Borderlands: Towards an Anthropology of the Cosmopolitan Condition, by Michel Agier]. Refuge, 34(1). https://doi.org/10.7202/1050860ar

Copyright (c) Refuge: Canada's Journal on Refugees, 2018

Creative Commons Attribution NonCommercial 4.0 International License

\section{(c) (i) \&}

This document is protected by copyright law. Use of the services of Érudit (including reproduction) is subject to its terms and conditions, which can be viewed online.

https://apropos.erudit.org/en/users/policy-on-use/ 


\title{
Review Essay
}

\author{
LAURA BISAILLON
}

\section{Refugees in Extended Exile: Living on the Edge}

Jennifer Hyndman and Wenona Giles

New York: Routledge, 2017, 164 pp.

\section{Borderlands: Towards an Anthropology of the Cosmopolitan Condition}

\author{
Michel Agier \\ Cambridge: Polity, 2016, 186 pp.*
}

I weave together common threads of two incisive, humane, articulate, and complementary books-Refugees in Extended Exile: Living on the Edge and Borderlands: Towards an Anthropology of the Cosmopolitan Condition. Both make highly original and timely contributions to the fields of anthropology, geography, migration, and political studies. They will appeal and be useful to researchers, students, and practitioners interested in questions, such as: What does it feel like to be a person in need of state protection? To be a refugee, faced with little choice but to live and raise children in exile for years without foreseeable end? What does it look like to live one's life in the liminal spaces between disparate places, such that you are not fully a part of any of these?

We traverse the geographies and encounter the histories and present-day conditions in parts of Africa, Europe, the Middle East, and North America. We encounter myriad ways that people and places have been and are connected in transnationally discernable ways. Hyndman and Giles's book emerges from their "global homelessness project" (22), which was motivated by refugees' "tenacity and strength despite the challenges of protracted displacement" (xvi). They aim to inform efforts that address deleterious effects of perennial expatriation. Agier sets out to disrupt status quo thinking about mobility and the so-called other by showing how our world is blended or "cosmopolitan." Both books are empirically grounded in field sites and convey that the authors have listened closely and compassionately to informants. Such shared commitments and approaches position the authors to distill, discern, and show us how and with what consequence social processes manifest in the lives of people we meet in these books.

Refugees in Extended Exile is an engrossing and important study of extended human dislocation. In six chapters Hyndman and Giles illuminate social processes and politi$\mathrm{cal}$ arrangements that position refugees to live in persistent displacement. What mechanisms enable and support this situation of uncertainty? What would it mean to rupture such conditions, releasing people from limbo? These questions gnawed at the authors, compelling inquiry. We are necessarily troubled by the findings unearthed. Refugees in

* Originally published as La condition cosmopolite: Lanthropologie à l'épreuve du piège identitaire (Paris: Éditions La Découverte, 2013).

(C) Laura Bisaillon, 2018. This open-access work is licensed under a Creative Commons Attribution-NonCommercial 4.0 International Licence, which permits use, reproduction, and distribution in any medium for non-commercial purposes, provided the original authorship is credited and the original publication in Refuge: Canada's Journal on Refugees is cited.
Cette œuvre en libre accès fait l'objet d'une licence Creative Commons Attribution-NonCommercial 4.0 International License, laquelle autorise l'utilisation, la reproduction et la distribution de l'œuvre sur tout support à des fins non commerciales, pourvu que l'auteur ou les auteurs originaux soient mentionnés et que la publication originale dans Refuge: revue canadienne sur les réfugiés soit citée. 
long-term displacement have little choice but to habituate to "ontological insecurity" (37) as an organizer of their existence. This means foreclosure in knowing or shaping the future with a measure of certainty. How this foreclosure is socially produced, organized, and sustained is explored. Impediments to resolving long-term exile for refugees in Kenya and Iran are visible through their analyses.

This book is organized into empirical $(3,5)$ and theoretical $(2,4)$ chapters, in addition to an introduction and conclusion. In chapter 2, a problematic is foregrounded: during lengthy displacement, tension between notions of protection and national security is rife. A tenacious contemporary narrative marries the refugee and state security concerns. At once over-general and harmful, this connotation politicizes and places the refugee within the frame and logic of risk and harm. In the international refugee apparatus, long-term displacement is a containment strategy. Worldwide, we are seeing at once a reduction in protecting people in need and a rise in ways to preclude, exclude, watch, and warehouse them.

What does it look and feel like to live in extended exile? Chapter 3 affords us glimpses into people's lives to answer this question. We are brought into the lives of Afghans living in Iranian cities. We learn about the living conditions and circumstances of Somalis residing in Nairobi and in Dadaab refugee camp, Kenya. (The book's two maps appear in this chapter, helping us to visualize spatial relations.) Analytically, the authors task themselves with having us see people in "relational ways" (49) so that we can appreciate and develop understandings about their predicaments. Refugees are thus humanized for us through stories of loss and suffering produced by chronic precariousness. The authors make connections between their work and the rich body of scholarship from the geographies explored.

Chapter 4 analyzes how countries including Kenya, Uganda, South Africa, and Tanzania have managed refugees in extended dislocation by using policy and legal instruments. We are offered a fascinating timeline and details about policy and legal history and practices in and between these countries. The authors ask us to reflect on opportunities and challenges that exiled people living in these jurisdictions face, including what approaches were tried and which worked well and less well and why. They also ask us to think about alternatives to onward resettlement to another country. Hyndman and Giles marshal the ideas of Giorgio Agamben, Hannah Arendt, Judith Butler, Alison Mountz, Patricia Owens, and Miriam Ticktin, among others, to nourish their analysis and produce novel insights about the politics of long-term displacement.

What about resettlement as a response to life in protracted exile? Chapter 5 documents the surprises, tensions, and contradictions that refugees, who had previously lived in extended expatriation in Iran and Somalia and who were resettled to Canada, confront. This chapter opens our eyes to what is gained and lost through immigration. We are privy to people's decision-making and happiness, yes, but also to their ambivalence, melancholy, and musings about what it might have been like to stay behind. What also makes this chapter intriguing is how the material chafes with the ideological notion that Canada is a country "everybody in their right mind" would want to inhabit. Perspectives of those who settled after living in prolonged displacement tell a markedly dissimilar story.

Borderlands is a compelling study of life in spaces on the edges of/in between nations. Agier uses the history and materiality of borders and walls-devices that are meant to divide, block, and bound-to focus analytic attention on social relations that develop in these dynamic places. As locations of juncture and transience, migrants find themselves inside and outside official national spaces. As sites of flux, borders oblige people to experience difference, experience themselves as different, and to adapt to newness.

Agier's book is organized into two parts to be read "successively or in parallel" (ix). In the first section he advances the idea that experiencing the unfamiliar is an increasingly universal process shaped by global movement and trade. As to the need to acclimatize and learn the ways of the socalled other, he posits that this is an endemic trait of the "cosmopolitan condition," defined as "the experience of the roughness of the world by all those who, by taste, necessity or compulsion, by desire or by habit, are left to live in several places almost simultaneously and, in the absence of ubiquity, to live increasingly in mobility, even in an in-between" (ix). While this imperative to acclimatize might be most obvious in the effort migrants undertake, Agier argues that this condition is "likely to become the most widespread social and cultural way of life in a near future already in the process of construction" (11-12). In the second section we read about the practical and conceptual tools and actions to fulfill these conditions. The tome culminates in a call to explore the lineaments of cosmopolitanism as practice.

These books were researched and written during overlapping periods in the first decades of the twenty-first century. It follows, then, that the authors take issue with and ultimately reject the increasingly frequent conflation of migrants with risk, terror, and security. The authors recognize and problematize these analytic moves as decontextualized expressions of political reaction and agenda setting. The accurate framing, Hyndman and Giles emphatically state, is to see migrants' lives as "barometers" of widespread social anxiety and problems, not as causes of ills. In the same vein Agier suggests that migrants are indicators of social processes and 
transformations that have long been underway. That is, in experiencing the unfamiliar and adapting to uncertainty, we are urged to see the conjunction between migrants and ourselves as inhabitants of an intertwined world.

The academic genealogy in which these collections are steeped makes them exciting bedfellows. Self-proclaimed "undisciplined feminist bricoleurs" (21), Hyndman and Giles produce fine analysis using an opulent pool of ideas from Anglo-American and also Continental European realms, including works by Agier. With an equally thrilling dose of "intellectual promiscuity" and squarely within anthropology and ethnology, Agier delves into the recesses of Continental European, African francophonie and Latin American founts of knowledge and beyond. We are privy to a veritable tour de force of social scientific thinking about migration in historical and contemporary environments.

What do Hyndman, Giles, and Agier ask in return for reading Refugees in Extended Exile and Borderlands? First, that we take a humanist stance and gaze to engage the five senses in our conceptual and embodied relations with migrants, mobile people, refugees in expatriation, and the constellation of actors whose professional lives come into being through and depend on their presence in borderlands and exile. We are asked to forefront the human behind the headline by situating the person within the politics in which she or he lives. Doing so can safeguard against the possibility that these people and conditions disappear into the jargon of the international refugee apparatus and the rationalities of the nation-state system, which, unless we pay attention to how we use them, can distract and distort to harmful effect.

Second, the volumes ask that we exercise reflexivity and see transformations that happen when we over-simplify and over-generalize messaging produced about migrants, mobile people, and refugees in exile. A priority action, the three authors agree, is casting off of the binary "us and them." This point couples their ideas with those of Lemn Sissay ${ }^{2}$ (2016). His poem shows how this dualism is an ahistorical falsehood unsynchronized with the multi-local world that exists, which, as Hyndman, Giles, and Agier show, has actually always existed as such.

\section{Immigration R.S.V.P.}

The lemons you suck are from Spain The orange you drink's from South Africa. Shoes you wear are made in Pakistan And your oil is from Saudi Arabia.

You import your petrol from the Gulf States Your toys are made in Taiwan.

Your coffee they send from Colombia Your cars are driven from Japan.

You've flooded yourself with foreign good But foreigners, you tell me, are bad.

You say you're afraid that we'll over run you But I'm afraid we already have.

Finally, Hyndman, Giles, and Agier ask that we use their analyses. For example, I will not employ the concepts "protracted refugee situation" and "durable solution" as easily as I might have before reading these books. Both volumes are suitable for social science and humanities classrooms. For undergraduates, delving into particular excerpts would be a good strategy. For graduates, the full-length publication would expose students to the breadth of intellectual sources that they could use in their work. These books provide valuable places for students to see how to use social theory that stretches across disciplines. They also learn what theoretically informed empirical work looks like. I hope that Hyndman, Giles, and Agier would agree that these are fertile ways to broadcast their timely, erudite, and high-spirited scholarship.

\section{Notes}

1 L. Bisaillon, "Practicing Intellectual Promiscuity: A Professor's Response," Underground 37, no. 3 (2017): 28-9, https://www.academia.edu/35589808/Practicing_ Intellectual_Promiscuity.

2 L. Sissay, Gold from Stone Crows Nest: Allen \& Unwin Canongate, 2016.

Laura Bisaillon is assistant professor at the University of Toronto. She can be reached at lbisaillon@utsc.utoronto.ca. 